\title{
Constraints to and conservation implications for climate change adaptation in plants
}

\author{
Matthew J. Christmas ${ }^{1}$ - Martin F. Breed ${ }^{1} \cdot$ Andrew J. Lowe ${ }^{1}$
}

Received: 19 April 2015/Accepted: 15 September 2015/Published online: 24 September 2015

(C) The Author(s) 2015. This article is published with open access at Springerlink.com

\begin{abstract}
Contemporary climate change is having widespread impacts on plant populations. Understanding how plants respond to this change is essential to our efforts to conserve them. The key climate responses of plant populations can be categorised into one of three types: migration, in situ adaptation, or extirpation. If populations are to avoid extirpation then migration and/or in situ adaptation is essential. In this review we first articulate the current and future constraints of plant populations, but trees in particular, to the different adaptation strategies (e.g. space availability, rate of change, habitat fragmentation, niche availability). Secondly, we assess the use of the most appropriate methods (e.g. natural environmental gradients, genome and transcriptome scans) for assessing and understanding adaptive responses and the capacity to adapt to future challenges. Thirdly, we discuss the best conservation approaches (e.g. assisted migration, biodiversity corridors, ex situ strategies) to help overcome adaptive constraints in plants. Our synthesis of plant, and particularly tree, responses and constraints to climate change adaptation, combined with the identification of conservation strategies designed to overcome constraints, will help deliver effective management actions to assist adaptation in the face of current and future climate change.
\end{abstract}

Andrew J. Lowe

andrew.lowe@adelaide.edu.au

Matthew J. Christmas

matthew.christmas@adelaide.edu.au

Martin F. Breed

martin.breed@adelaide.edu.au

1 Environment Institute and School of Biological Sciences, The University of Adelaide, North Terrace, SA 5005, Australia
Keywords Adaptive capacity - Ecological restoration Genetic resource management - Gene flow · Genomics . Global change

\section{Introduction}

In response to contemporary climate change plants can adapt, migrate, or die (Aitken et al. 2008) (Fig. 1a-e). During Quaternary climate fluctuations migration was a common response, particularly in the northern hemisphere (Pardi and Smith 2012). How plants will respond during the current period of warming is less clear as plants are facing unprecedented rates of anthropogenically-induced climate change, which has no past analogue (Thomas et al. 2004). Climatic envelopes are generally shifting polewards and upwards (Parmesan and Yohe 2003), which is putting pressure on plant populations to shift their ranges to track optimal climatic conditions (Parmesan 2006; Pardi and Smith 2012; Fig. 1b). Indeed, shifts in species distributions in line with temperature shifts have already been observed across a range of plant taxa (Sturm et al. 2001; Parmesan and Yohe 2003; Jump and Peñuelas 2005; Hickling et al. 2006; Beckage et al. 2008).

The 'first line' response to a changing climate may therefore be migration-a geographic shift in distribution via seed dispersal into climatically suitable areas (Fig. 1b). However, such shifts may not be straightforward. In an analysis of USDA Forest Inventory and Analysis data from across the eastern United States, $58.7 \%$ of 92 tree species showed indications of range contraction at both northern and southern boundaries of their distribution (Zhu et al. 2012). Only $20.7 \%$ of species exhibited patterns consistent with a northward shift, and crucially, evidence was particularly lacking for population spread in areas where 


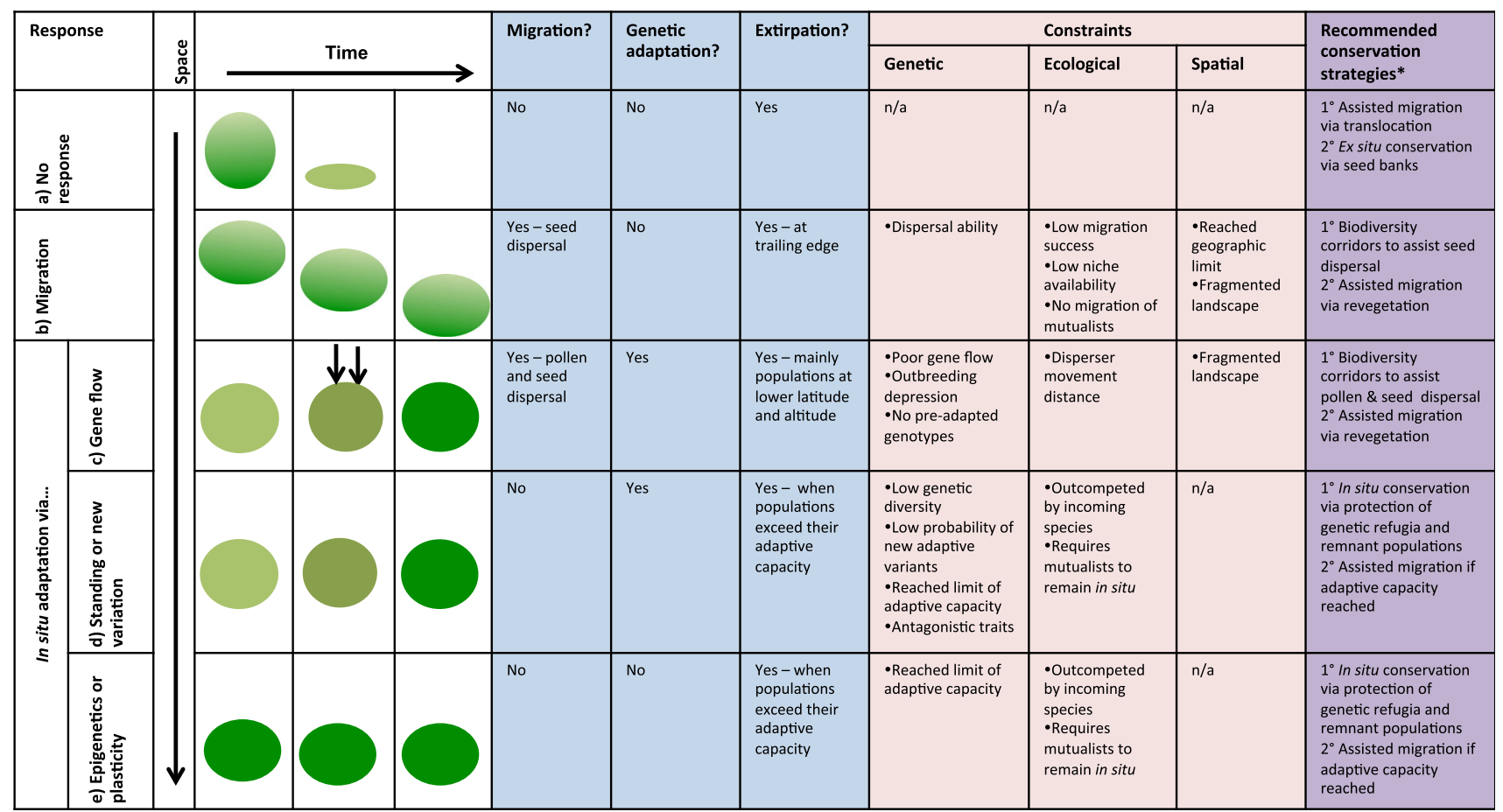

Fig. 1 Plant responses to climate change, constraints on these responses, and conservation strategies best suited to overcoming these constraints. Coloured circles represent populations. Shade of green indicates how well adapted the average phenotype is to the

climate had changed the most. This suggests that migration may not be as common as expected, and potentially puts populations at higher risk of becoming increasingly maladapted over time. Under the projected high rates of future climate change, successful migration may also rely on the evolution of ever longer dispersal distances in order to enable species to reach suitable new habitat.

If species fail to sufficiently migrate then adaptation in situ will be essential for persistence (Fig. 1c-d). The ability to adapt in situ will rely upon a wide range of factors. These include (1) heritable trait variation (i.e. trait variation attributable to genes) within populations for selection to act upon; (2) levels of gene flow from populations at lower latitudes/altitudes introducing 'pre-adapted' alleles to, or more generally increasing genetic variation within, populations at higher latitudes/altitudes (Sexton et al. 2011; Kremer et al. 2012); and (3) the chance occurrence of new advantageous mutations arising within populations. However, the likelihood of new adaptive alleles arising, particularly those of large effect (as may be required under rapid climate change; Reed et al. 2011), is very low. The presence of standing heritable genetic variation that can provide a fitness advantage under new climatic conditions would bestow populations with the best chances of adapting in situ. environment; bold green well adapted, light green maladapted. Arrows in (c) represent gene flow. *The use of seed banks could be employed under all scenarios to safeguard against loss of genetic diversity due to population extirpation

An alternative to genetic-based adaptation is epigenetic or plastic responses (Fig. 1e). Trait plasticity can result in a wide range of phenotypes occurring in the same genetic background, acting as a buffer to environmental changes (Ghalambor et al. 2007; Nicotra et al. 2010). There is now increasing evidence that some heritable variation in ecologically relevant traits is not caused by genes but is instead stimulated by epigenetic mechanisms that alter gene activity through targeted molecular processes (Fieldes and Amyot 1999; Molinier et al. 2006; Yakovlev et al. 2011). In particular, DNA methylation and histone post-translational modifications are key mechanisms for gene-expression regulation and development in plants. These mechanisms can bring about a rapid $(<1$ generation) adaptive response to environmental change (Bossdorf et al. 2008; Rival et al. 2012).

If populations fail to adapt or migrate under climate change then, as conditions become more unsuitable, extirpation and extinction may be unavoidable (Fig. 1a). Mass extinction events have had a strong association with major climatic change over the past 520 million years, with low levels of global biodiversity and high extinction rates prevalent immediately following periods of major temperature change (Mayhew et al. 2008). Extinctions linked to contemporary climate change have already been observed for a number of animal groups (e.g. checkerspot 
butterflies, McLaughlin et al. 2002; and frogs, Pounds et al. 2006), but as yet there are no reports of climate driven extinctions in plants. There is, of course, the possibility that some species will persist without migration or genetic adaptation by, for example, exploiting microclimatic variation within their current range (e.g. populations move from sun to shade, from dry slopes to seeps), through facilitative interactions with other local plant species (Brooker et al. 2008), or endophytic relationships with soil microbes (Lau and Lennon 2012). Increasing our understanding of the ways that plant species are likely to respond under climate change, and particularly of the constraints that restrict the adaptive responses of species and populations, is integral to our attempts to conserve species.

There have been a number of recent reviews on plant responses to climate change, each with a different emphasis (e.g. Davis and Shaw 2001; Walther 2003; Jump and Peñuelas 2005; Aitken et al. 2008; Anderson et al. 2012; Corlett and Westcott 2013). For example, Aitken et al. (2008) looked specifically at trees and Corlett and Westcott (2013) predominantly considered migrational responses across all taxa. Here, we provide an updated appraisal of the most recent literature on plant responses to contemporary climate change. We focus mainly on the threats caused by direct climate effects (i.e. changes in temperature and rainfall), with climate envelopes shifting towards the poles, while acknowledging that climate change is complex and its effects will not be felt equally across all environments and locations. More complex/synergistic impacts of global change have been discussed elsewhere (e.g. Brook et al. 2008). While we consider the responses of both short- and long-lived species, our review pays particular attention to the responses of and potential impacts on tree species. Our review is focussed on three largely neglected aspects. Firstly, we focus on key constraints to responses to climate change. Secondly, we discuss the best approaches to assess adaptive potential in plants, highlighting the use of environmental gradients and genome and transcriptome scans to understand the type, magnitude and rate of adaptive responses. Thirdly, we consider the best conservation approaches to help overcome adaptive constraints in plants. We discuss how this information can be integrated into conservation actions to help prevent species extinctions as well as facilitate on-going adaptation to climate.

\section{Constraints to climate change adaptation}

Through a literature search, we have identified a non-exhaustive collection of studies that identify constraints to adaptation in a wide range of plant species (Table 1). These studies have expanded our understanding of the factors that constrain the adaptive capacity of plants, and can therefore be used to target conservation practices to overcome these constraints. Figure 1 provides a summary of the constraints to each adaptive response, which have been divided into three categories: spatial (and temporal), ecological, and genetic constraints. Recommended conservation strategies for overcoming each constraint are also provided (discussed in Sect. 4).

\section{Constraints to migration (Fig. 1b)}

The ability of a species to shift its range will depend on several factors, such as the presence of suitable space to migrate into (including niche space), sufficient time to migrate (in terms of generation time, age to maturity, seed dispersal distance), a connected landscape, and the presence/migration of co-dependent species into the new range. If any of these factors are not realised then successful migration may prove difficult. We consider each of these in turn in order to illustrate their importance.

\section{Available and suitable space to migrate into}

Range shifts may be a successful response particularly if only short migration distances are required, such as up slope to higher elevation. Within the Snowy Mountains of Australia, every $100 \mathrm{~m}$ increase in altitude is coupled with a temperature decrease of $\sim 0.77{ }^{\circ} \mathrm{C}$ (Brown and Millner 1989). Climate change predictions for the Australian Alps suggest that by 2050 , temperatures will increase by between $0.6{ }^{\circ} \mathrm{C}$ (low impact scenario) and $2.6{ }^{\circ} \mathrm{C}$ (high impact scenario) (Hennessy et al. 2003). These predictions equate to a $78 \mathrm{~m}$ upward temperature shift under low impact temperature increases, or a $338 \mathrm{~m}$ upward shift under the high impact scenario. The high impact scenario is concerning for mountaintop restricted species. At the highest summit sampled in the Snowy Mountains by Pickering et al. (2008), there was only $114 \mathrm{~m}$ of mountain area above the highest recorded species. If temperatures increase by $0.9{ }^{\circ} \mathrm{C}$ (closer to the current most conservative estimates) then these species may run out of altitudinal range to migrate into. The Haleakalā silversword (Argyroxiphium sandwicense subsp. macrocephalum) on the Hawaiian island of Maui is just one more example of where this threat is being realised (Krushelnycky et al. 2013). Species migrating along a latitudinal rather than altitudinal gradient will experience similar issues if they reach the edge of habitable land (e.g. a coastal boundary for terrestrial plants).

\section{Sufficient time to migrate}

The study of fossil pollen distribution data has led to the inference that past migration rates of plants in response to 
Table 1 A selection of meta-analyses, empirical, and modelling studies where constraints to adaptation, via migration, in situ adaptation, or both, have been identified or predicted

\begin{tabular}{|c|c|c|c|c|c|c|c|}
\hline Species & Plant form & Study region & $\begin{array}{l}\text { Type of } \\
\text { study }\end{array}$ & $\begin{array}{l}\text { Adaptation } \\
\text { strategy }\end{array}$ & $\begin{array}{l}\text { Adaptation } \\
\text { constraint }\end{array}$ & Main findings & Reference \\
\hline 92 tree species & Trees & Eastern USA & $\begin{array}{l}\text { Meta- } \\
\text { analysis }\end{array}$ & Migration & Unknown & $\begin{array}{l}\text { Only } 20.7 \% \text { of species } \\
\text { showed northward } \\
\text { migration } \\
58.7 \% \text { showed range } \\
\text { contractions at both } \\
\text { northern and southern } \\
\text { boundaries }\end{array}$ & $\begin{array}{l}\text { Zhu et al. } \\
\text { (2012) }\end{array}$ \\
\hline $\begin{array}{l}\text { Haleakalā } \\
\text { silversword } \\
\text { (Argyroxiphium } \\
\text { sandwicense ssp. } \\
\text { macrocephalum) }\end{array}$ & Herb & $\begin{array}{l}\text { Maui, } \\
\text { Hawai'i }\end{array}$ & Empirical & Migration & $\begin{array}{l}\text { Insufficient } \\
\text { space }\end{array}$ & $\begin{array}{l}\text { Endemic species restricted } \\
\text { to a single volcano } \\
\text { summit } \\
\text { Experienced high mortality } \\
\text { at low altitude and } \\
\text { increased water stress, } \\
\text { putting the entire species } \\
\text { at risk }\end{array}$ & $\begin{array}{l}\text { Krushelnycky } \\
\text { et al. (2013) }\end{array}$ \\
\hline $\begin{array}{l}27 \text { northern plant } \\
\text { species }\end{array}$ & Various & $\begin{array}{l}\text { Northern } \\
\text { hemisphere } \\
\text { alpine and } \\
\text { arctic zones }\end{array}$ & Modelling & $\begin{array}{l}\text { Migration } \\
\text { and in situ } \\
\text { adaptation }\end{array}$ & $\begin{array}{l}\text { Dispersal } \\
\text { ability }\end{array}$ & $\begin{array}{l}\text { Spatial distribution } \\
\text { modelling predicted loss } \\
\text { of genetic diversity was } \\
\text { largely determined by } \\
\text { dispersal ability } \\
\text { Short-distance dispersers } \\
\text { (e.g. herbs) would lose } \\
\text { more genetic diversity } \\
\text { than long-distance } \\
\text { dispersers }\end{array}$ & $\begin{array}{l}\text { Alsos et al. } \\
\text { (2012) }\end{array}$ \\
\hline $\begin{array}{l}\text { Partidge Pea } \\
\quad \text { (Chamaecrista } \\
\text { fasciculata) }\end{array}$ & Herb & $\begin{array}{l}\text { US Great } \\
\text { Plains }\end{array}$ & Empirical & $\begin{array}{l}\text { In situ } \\
\text { adaptation }\end{array}$ & $\begin{array}{l}\text { Trait/gene } \\
\text { interactions }\end{array}$ & $\begin{array}{l}\text { Despite significant levels of } \\
\text { genetic variation in a } \\
\text { number of adaptive traits, } \\
\text { the rate of evolution of all } \\
\text { traits together was slower } \\
\text { than that expected for the } \\
\text { independent evolution of } \\
\text { individual traits }\end{array}$ & $\begin{array}{l}\text { Etterson and } \\
\text { Shaw (2001) }\end{array}$ \\
\hline $\begin{array}{l}\text { Dryas octopetala; } \\
\text { Eriophorum } \\
\text { vaginatum }\end{array}$ & $\begin{array}{l}\text { Shrub; } \\
\text { Perennial } \\
\text { herb }\end{array}$ & Alaska & Empirical & $\begin{array}{l}\text { In situ } \\
\text { adaptation }\end{array}$ & $\begin{array}{l}\text { Lack of } \\
\text { plasticity }\end{array}$ & $\begin{array}{l}\text { After } 30 \text { years of reciprocal } \\
\text { transplant experiments, } \\
\text { local provenances } \\
\text { significantly } \\
\text { outperformed foreign } \\
\text { provenances } \\
\text { No evidence was found for } \\
\text { plasticity aiding the } \\
\text { persistence of foreign } \\
\text { provenances }\end{array}$ & $\begin{array}{l}\text { Bennington } \\
\text { et al. (2012) }\end{array}$ \\
\hline $\begin{array}{l}32 \text { herbaceous } \\
\text { plants }\end{array}$ & Herb & $\begin{array}{l}\text { Temperate } \\
\text { regions }\end{array}$ & $\begin{array}{l}\text { Meta- } \\
\text { analysis }\end{array}$ & $\begin{array}{l}\text { In situ } \\
\text { adaptation }\end{array}$ & $\begin{array}{l}\text { Small } \\
\text { population } \\
\text { size }\end{array}$ & $\begin{array}{l}\text { Meta-analysis of reciprocal } \\
\text { transplant experiments } \\
\text { revealed that population } \\
\text { size had a significant } \\
\text { effect on local adaptation } \\
\text { Small populations ( }<1000 \\
\text { flowering plants) showed } \\
\text { less local adaptation, } \\
\text { inferred to be due to low } \\
\text { adaptive potential driven } \\
\text { by strong genetic drift }\end{array}$ & $\begin{array}{l}\text { Leimu and } \\
\text { Fischer } \\
\text { (2008) }\end{array}$ \\
\hline
\end{tabular}


Table 1 continued

\begin{tabular}{lllllll}
\hline Species & Plant form & Study region & $\begin{array}{c}\text { Type of } \\
\text { study }\end{array}$ & $\begin{array}{c}\text { Adaptation } \\
\text { strategy }\end{array}$ & $\begin{array}{l}\text { Adaptation } \\
\text { constraint }\end{array}$ & Main findings \\
\hline 52 plant species & Various & Various & $\begin{array}{c}\text { Meta- } \\
\text { analysis }\end{array}$ & $\begin{array}{c}\text { In situ } \\
\text { adaptation }\end{array}$ & $\begin{array}{c}\text { Habitat } \\
\text { fragmentation }\end{array}$ & $\begin{array}{c}\text { Meta-analysis of effect of } \\
\text { habitat fragmentation on } \\
\text { genetic diversity showed } \\
\text { that common species are } \\
\text { Jacemyn } \\
\text { as much at risk as rare } \\
\text { species, thus reducing } \\
\text { their adaptive potential } \\
\text { under climate change }\end{array}$ \\
\hline
\end{tabular}

The main adaptation strategy under study is identified along with the constraint restricting such adaptation

climate change were rapid and covered large distances (Davis 1981; MacDonald 1993; King and Herstrom 1997). However, the analysis of molecular data to infer postglacial expansion of two North American tree species suggests that estimates based purely on palynological data may be inaccurate and rates of postglacial spread are likely to have been much slower than previously interpreted (Petit et al. 2002; McLachlan et al. 2005; Lowe et al. 2005b). Therefore, predictions of rapid future plant migration inferred from palynological studies may be overestimating the migrational capacity of plants. A decrease in range size resulting from an inability to keep up with climate change may thus be a more realistic scenario.

The ability of a plant species to keep up with a shifting climate envelope is determined by the rate of climate change, the distance over which it is able to migrate per generation and its seed dispersal effectiveness (Corlett and Westcott 2013). Velocity of climate change algorithms have been used to estimate the likelihood of species to keep up with a shifting climate envelope. These algorithms divide the rate of climate change by the rate of spatial climate variability in order to calculate the speed by which species must migrate to maintain constant climate conditions (Loarie et al. 2009). This approach has recently been used to identify vulnerable species in need of conservation management (Hamann et al. 2015).

The seed dispersal of many species is described as leptokurtic, where most seed is dispersed near the maternal plant, with relatively little dispersed over longer distances. Plant species that have long distance seed dispersal will have greater success of dispersing into climatically suitable areas (Davies et al. 2004; Pearson and Dawson 2005). Modelling the dispersal of trees in the eastern United States over the next 100 years suggests that the probability of colonisation within $10-20 \mathrm{~km}$ of current boundaries is high, but longer distance dispersal events $(>20 \mathrm{~km})$ are unlikely to result in colonisation (Iverson et al. 2004a). These longer distance dispersal events may be necessary to keep up with optimal conditions, particularly for long lived species with long generation times such as trees. Indeed, required migration rates in excess of $100 \mathrm{~m}$ per year have been predicted (Higgins et al. 2003).

Nei et al. (1975) suggested that a cost to the reliance on long-distance dispersal for survival will be a reduction in population size and allelic richness, leading to reduced adaptive potential. However, dispersal distance is a trait that evolves. In their review of life-history evolution in populations experiencing range-shifts, Phillips et al. (2010) concluded that assortative mating as a result of climate change may result in an increased rate of evolution of lifehistory traits that promote dispersal distance and reproductive rate at the leading edge. Seed dispersal is a highly labile trait in plants and, as the best-dispersing individuals within a population should be highly represented at the leading edge of the new range, the chance of breeding between 'good dispersers' should be high, resulting in runaway natural selection for dispersal rate at the leading edge (Phillips et al. 2010; Boeye et al. 2012, Kremer et al. 2014).

At the newly colonised edge of a species' range, population density will be low and individuals will inhabit an $r$-selective environment where high reproductive and dispersal rates are advantageous (Rejmánek and Richardson 1996; Phillips et al. 2010). Predictive models have suggested that increased rates of climate change will select for larger dispersal distances, providing a rescue mechanism for populations to cross large gaps in suitable habitat (Boeye et al. 2012). However, at least one modelling study has suggested that high dispersal rates will actually hamper adaptive evolution and will in fact increase extinction risk due to the shifting ranges of some species causing the decline in others (Norberg et al. 2012). Overall, modelling (Iverson et al. 2004a, b; Feeley and Silman 2010), experimental (Ibanez et al. 2008, 2009) and survey studies (Zhu et al. 2012) combine to suggest that migration rates are likely to be below those required to track contemporary climate change. 


\section{A connected landscape}

Historically, landscape connectivity would have been greater due to a lack of anthropogenic habitat clearance. Migration across the landscape may therefore have been more straightforward than it is today (Davis and Shaw 2001; Pardi and Smith 2012). Indeed, the current scale of habitat fragmentation is likely to hamper the potential success of migration (Davis and Shaw 2001; Hoffmann and Sgro 2011). Successful migration relies heavily upon the connectedness of populations across suitable environments, particularly in species with short dispersal distances (Pearson and Dawson 2005). Modelling studies predict that habitat fragmentation will have a large impact on the ability of plants to migrate across landscapes and that the connection of remnant fragments via corridors and restoration may greatly assist plant persistence (Higgins et al. 2003; Renton et al. 2012, 2013). The landscape does not necessarily need to be continuous, but distances between populations or fragments need to be short enough to enable successful dispersal. For example, scattered trees in fragmented landscapes have been identified as having a key role to play in aiding migration (Breed et al. 2011), and provide a connective link between remnant vegetation via seed dispersal (Bacles et al. 2006; Sork and Smouse 2006).

\section{Co-migration of dependencies}

A recent systematic review of the causes of contemporary climate change-related extinctions revealed that changes in species interactions are an important cause of population decline (Cahill et al. 2013). Many species of plants rely heavily on other species for a number of essential services, such as pollination, seed dispersal, and nutrient provision. If plant service providers migrate across the landscape at different rates then ecological decoupling may lead to plant population decline and extirpation. This scenario also opens up the potential for novel combinations of species in future communities; modelling of multiple competing species along a warming climate gradient predicts that communities of species with narrow niches, high interspecific dispersal variance, and strong competition are most under threat from the disruptive consequences of climate change (Urban et al. 2012).

Plants often depend on soil microbes to successfully establish, grow and survive in a range of habitats. As plant populations shift across the landscape the continued association with their symbiotic microbes may prove essential to their fitness in new environments (Pellissier et al. 2013). For example, plants with associated endophytes had a $20 \%$ broader climatic niche and were able to inhabit drier environments compared to plants without such associations (Afkhami et al. 2014). The soil type the associated endophytes are adapted to is also important, with one study demonstrating that plant fitness increased when grown in association with microorganisms adapted to the soilmoisture environment (Lau and Lennon 2012). These findings suggest that the success of plant responses to climate change may be in part driven by closely associated microbial communities. Lau and Lennon (2012) suggest that plants are therefore not just limited to a choice between adapt or migrate, but that rapid responses in the soil microbe community may also facilitate plant persistence.

\section{Constraints to in situ adaptation (Fig. 1c-e)}

The constraints to migration discussed above may mean that this adaptation route may be very limited and potentially unsuccessful (Corlett and Westcott 2013). This puts a larger emphasis on in situ adaptation for on-going population persistence (Fig. 1c-e). Factors affecting a population's ability to adapt in situ are numerous and we have selected the most pertinent ones here for discussion.

\section{Raw material for evolution: standing genetic variation and new mutations}

The level of heritable trait variation within a population will be a key factor in determining a population's adaptive potential under climate change. The term heritable variation refers to the amount of phenotypic variation in a population that has a genetic basis and is therefore available to be inherited by the next generation. The heritability of a trait (broad sense heritability $H^{2}$, and the more commonly estimated narrow sense heritability $h^{2}$ ) is the ratio of variation due to genetic differences (for $H^{2}$ this includes additive, dominance and epistatic effects; for $h^{2}$ this just includes additive genetic variance) to the total phenotypic variation $\left(V_{p}\right)$ for a given trait. Estimates of heritability range from 0 to 1 ; the closer the estimate is to 1 , the more the variation is explained by genetic, and therefore heritable, differences. The adaptive potential of a population can therefore be estimated by the amount of adaptive trait variation (Willi et al. 2006).

The more heritable trait variation there is within a population, the greater the variety of phenotypes for natural selection to act upon and, therefore, the greater the chance that a suitable adaptive phenotype already exists within the population. For example, large populations with extensive historical gene flow that have been exposed to large climatic variation in the past are likely to have high levels of heritable trait variation, whereas small populations that have been through recent bottlenecks would not. In their consideration of adaptive responses to climate change in plants, Jump and Peñuelas (2005) suggested that climatic 
differentiation within populations is a general pattern and that high levels of climate-related variation within populations bestows them with broad climatic optima. Populations with broad climatic optima may respond well to climate change, in the short term at least. For example, warm- and cold-year subpopulations (where mean temperatures in year of establishment differed by up to one degree centigrade) in a stand of birch displayed clear genetic segregation, providing evidence for adaptive capacity and the presence of 'pre-adapted' individuals to future temperature change (Kelly et al. 2003).

In small populations, or in other situations where heritable genetic variation is low, adaptation to novel conditions may rely upon the occurrence of new mutations. The probability of fixation of a new mutation is much lower than that for adaptive alleles already present within a population, since they are likely to be present in several individuals and will be immediately available for selection (Hermisson and Pennings 2005; Barrett and Schluter 2008). Low genetic diversity and a reliance on the occurrence of new adaptive mutations may strongly constrain a population's ability to adapt in situ.

In a meta-analysis of reciprocal transplant experiments investigating local adaptation in plants it was found that local adaptation is much more common in large populations ( $>1000$ flowering individuals) than small populations (<1000 individuals; Leimu and Fischer 2008). The absence of local adaptation in small populations was attributed to lower adaptive potential as a result of less heritable variation, fewer beneficial mutations, higher levels of inbreeding and/or genetic drift leading to the loss of advantageous alleles in comparison to large populations (Leimu and Fischer 2008). Small population size can therefore be considered a primary constraint to adaptive potential, thus putting small plant populations at risk of becoming ever more maladapted under a changing climate.

Dispersal success may also have a confounding effect on genetic diversity. Alsos et al. (2012) used spatial distribution modelling to predict the impact of climate change on range size and genetic diversity by 2080 of 27 northern hemisphere plant species. Their model predicted that a loss of genetic diversity was largely explained by dispersal ability (up to $57 \%$ ) as well as by genetic differentiation. A lack of long-distance dispersal ability, such as for herbs in their study, resulted in a higher predicted rate of genetic diversity loss compared to shrubs that have the capacity for long distance dispersal, thus reducing adaptive potential. An ability to successfully migrate over long distances will therefore not only help species to reach suitable habitats but also maintain higher levels of genetic diversity, increasing their adaptive potential into the future.

Even if significant levels of heritable trait variation exist, complex trait or gene interactions may restrict adaptive outcomes (Etterson and Shaw 2001; Lovell et al. 2013). Pleiotropy (one gene influencing multiple traits), polygenic traits (traits attributable to more than one gene) and antagonistic interactions among genes (e.g. linkage among genes for different traits under different selection pressures) may all constrain adaptation. For example, despite significant levels of genetic variation existing for a number of traits (e.g. fecundity, leaf thickness, leaf number and rate of phenological development) in the partridge pea (Chamaecrista fasciculata), the rate of evolution of all traits together was slower than the expected independent evolution of individual traits (Etterson and Shaw 2001). Thus, gene or trait interactions may restrict the rate of evolution, preventing species from adapting quickly enough to keep up with rapidly changing environments.

\section{Rate of climate change}

The rate of climate change will strongly influence whether there is sufficient time and generations for adaptation to occur. Average lifespan of individuals is an important determinant of adaptive capacity: the longer the generation time, the longer the adaptation lag and the greater the potential to be 'over-taken' by rapid climate change (Jump and Peñuelas 2005). As such, annual plants may have more opportunities for genetic-based adaptation and longer-lived species such as trees may have to rely more on redistribution of standing genetic variation via gene flow and/or adaptive trait plasticity (Nicotra et al. 2010; Franks et al. 2014) (see Sect. 2.2.4). For example, under a common garden set up, first flowering in the annual plant field mustard (Brassica rapa) has been demonstrated to occur up to 8.6 days earlier in post-drought plants when compared to their pre-drought ancestors (Franks et al. 2007). Ancestordescendant crosses resulted in offspring with intermediate flowering times, supporting an additive genetic basis for the divergence, and it was experimentally confirmed that summer drought selected for earlier flowering (Franks et al. 2007). Ancestors and descendants were collected from wild populations 7 years apart, so only a few generations were required for this drought adaptation to occur. Thus adaptive genetic responses are likely to be most prevalent in shortlived species.

Despite long generation times, the outlook for trees may not be so dire. In general, tree populations exhibit high genetic diversity (Kelly et al. 2003; Petit and Hampe 2006), high outcrossing rates (Petit and Hampe 2006; Breed et al. 2014) and high plasticity (Petit and Hampe 2006; Rico et al. 2014), which all act to equip trees with high adaptive potential (Davis and Shaw 2001). However, a rapid change in climate may act as a strong selective agent with the potential to radically erode climate-related genetic variation (Jump and Peñuelas 2005). Trees may therefore be 
able to cope with a changing climate in the short term, but if conditions reach unprecedented levels then they may struggle to adapt in the longer term.

\section{Connectedness of populations and level of gene flow}

Small, isolated plant populations resulting from habitat fragmentation generally experience increased genetic drift, elevated inbreeding and reduced gene flow, which in turn increases interpopulation genetic divergence (Lowe et al. 2005a; Vranckx et al. 2012; Breed et al. 2015). Fragmentation may also hamper the flow of adaptive alleles from lower to higher latitudes or altitudes, restricting the adaptive potential of populations. Although estimates of long distance gene flow suggest that genes can move more quickly than is required to track climatic shifts (Kremer et al. 2012), metaanalyses examining the genetic effects of habitat fragmentation have shown that fragmentation has a large and negative impact on population level genetic diversity and outcrossing rates (Lowe et al. 2005a; Honnay and Jacquemyn 2007; Aguilar et al. 2008; Eckert et al. 2010; Breed et al. 2012a; Vranckx et al. 2012; Breed et al. 2015). This seems to be the case for common species experiencing fragmentation as much as for rarer species, suggesting that vulnerability to genetic erosion and loss of genetic diversity is a common reality for plants in fragmented habitats (Honnay and Jacquemyn 2007). However there is evidence that gene flow dynamics may also be relatively robust to habitat fragmentation (e.g. Lowe et al. 2005a; Wang et al. 2011; Breed et al. 2012b). In a study into the effects of habitat fragmentation on genetic structure of the wind-pollinated, gravity seed-dispersed chinquapin tree (Castanopsis sclerophylla) no significant difference was observed in genetic diversity or inbreeding between pre- and post-fragmented populations, and this was attributed to extensive pollen dispersal (Wang et al. 2011). So, there may be some resilience to the immediate impacts of habitat fragmentation in tree populations, but reviews of the topic indicate that increasing impacts are likely to emerge in future generations (Lowe et al. 2005a; Honnay and Jacquemyn 2007; Vranckx et al. 2012; Breed et al. 2015; Lowe et al. 2015).

\section{Levels of plasticity}

Perhaps one of the most important mechanisms available to plants for coping with climate change is persistence through trait plasticity (Nicotra et al. 2010). This is a much understudied phenomenon that may have a large part to play in species adaptation and survival through the current period of warming, particularly for long-lived species (Petit and Hampe 2006). It is clear from the literature that levels of adaptive plasticity vary widely depending on species and trait, and predicting plastic responses to climate change is proving difficult (Nicotra et al. 2010). However, recent studies provide some interesting directions for learning in this area.

The analysis of survival and flowering in a dwarf shrub (Dryas octopetala) and a tussock-forming sedge (Eriophorum vaginatum) in two reciprocal transplant experiments 30 years after initial establishment showed that local adaptation was strong and that plasticity did not enable foreign populations to persist in novel sites (Bennington et al. 2012). For $E$. vaginatum, differential survival of populations was not found in the first 13 years of the experiment, suggesting that plasticity had a role to play during this period. However, after 17 years differential survival in line with local adaptation was evident (Bennington et al. 2012). This suggests that plasticity may mask local adaptation in the short term, but is not sufficient for long term persistence. Conversely, reciprocal transplant experiments of grassland species along an elevational gradient showed no indication of local adaptation, with consistent advanced reproductive phenology due to plasticity observed in all three species studied (Frei et al. 2014). Plasticity has also been demonstrated to assist Pinus species growth and survival under a warmer, drier climate (Richter et al. 2012). However, their findings were based on early seedling growth and the effectiveness of adaptive plastic responses in trees over the long term is unknown.

The level of adaptive trait plasticity and phenotype fitness will influence whether plastic responses are genetically assimilated (i.e. plastic traits that accumulate a genetic basis by natural selection; Ghalambor et al. 2007). If plasticity results in an optimal mean phenotype then stabilising selection should constrain genetic change. However, a suboptimal phenotype is likely to be subject to directional selection bringing populations closer to their fitness peak, thus ensuring long term adaptation to change (Ghalambor et al. 2007). Plasticity may therefore shield populations from the detrimental effects of climate change in the short term as well as assist long-term adaptation and persistence (Nicotra et al. 2010). If plasticity itself has a genetic basis (Anderson et al. 2011), then selection for greater adaptive plasticity under a more varied, less predictable climate could enable populations to better match environments in flux (Franks and Hoffmann 2012). This may explain the high levels of plasticity observed in long-lived trees, where an advantage is presumably gained to surviving long term fluctuating environments (Petit and Hampe 2006).

\section{New research tools for assessing climate adaptation in plants}

A range of methods has been employed to investigate and predict plant adaptation under climate change, such as space-for-time substitutions, common garden and 
reciprocal transplant experiments, and genomic methods to search for signatures of selection and local adaptation. Here, we review the key methods that we feel hold great promise for advancing our understanding of responses to climate change and, in turn, can directly inform future conservation strategies.

\section{Space-for-time substitutions, environmental gradients and phenotypic clines}

Phenotypic clines in adaptive traits over latitudinal or altitudinal gradients are common in plants (e.g. Etterson 2004; Maron et al. 2004; Uribe-Salas et al. 2008; Bresson et al. 2011; Montesinos-Navarro et al. 2011; Chen et al. 2012; Woods et al. 2012). Reciprocal transplant and common garden experiments have been used to determine the degree of plastic versus heritable variation in clinal traits. A good example of adaptive clinal variation along environmental gradients is the work of Etterson (2004), who studied the partridge pea (Chamaecrista fasciculata) along a latitudinal gradient (from Minnesota to Oklahoma, USA). Across this gradient, mean annual temperature ranged from 17 to $23{ }^{\circ} \mathrm{C}$. Clinal variation and genetic divergence had been previously shown in this species (Etterson 2000). To test for adaptive differences along the gradient, reciprocal transplant experiments were carried out in Minnesota, Kansas and Oklahoma. Northern populations grown in the south (i.e. mimicking predicted climate change) were found to have substantially lower fitness, despite demonstrating considerable phenotypic plasticity when in non-native sites. These results demonstrated that different phenotypes were favoured under different climatic conditions and Etterson (2004) suggested that, as the climate becomes warmer and drier in the Great Plains, evolutionary change will be required to maintain optimal population fitness.

A study into the altitudinal variation of functional traits in European oak and beech set out to evaluate the basis of genetic adaptation (Bresson et al. 2011). Several morphological and physiological leaf functional traits were found to vary along two altitudinal gradients. For example, leaf physiological performance (e.g. higher maximum rates of assimilation, stomatal conductance and leaf nitrogen content) was significantly greater in plants at higher altitudes. Through the use of common garden experiments Bresson et al. (2011) demonstrated that genetic differences accounted for only a small amount (0-28\%) of phenotypic variation, suggesting that trait plasticity is responsible for the majority of the observed variation. As alluded to earlier, the long generation times of tree species may have resulted in strong selection for increased trait plasticity.

Environmental gradients can also provide excellent natural laboratories for studying isolation by distance
(IBD; Wright 1943) versus isolation by ecology (IBE; Sexton et al. 2014; Shafer et al. 2015), where locally adapted populations can inhabit close geographical space but disparate ecological space (particularly along altitudinal gradients). Real promise lies in the use of multiple independent transects along the same environmental gradients, which can be utilised as evolutionary replicates. Such study designs would provide great insight into adaptive evolution, its genetic basis and its redundancy, as well as the interactions between selection and migration (Savolainen et al. 2013).

\section{The genomics era: signatures of selection and gene expression}

The application of genomics technologies to conservation practice has been discussed in two recent reviews (Hoffmann et al. 2015; Shafer et al. 2015). There has also been a focus in the recent literature on the use of genomics for investigating natural selection, with particular attention paid to the promise and pitfalls of using genomic data for identifying loci associated with environment/climate (Schoville et al. 2012; Vitti et al. 2013; Tiffin and RossIbarra 2014; Bragg et al. 2015). Here, we consider two genomic techniques that hold real promise in advancing our understanding of plant adaptation and highlight how we can use this knowledge to more clearly direct conservation actions. It is important to note, however, that the use of molecular markers as a measure of a population's adaptive potential can be unreliable (Mittell et al. 2015) and so the identification of levels of genetic variation among genetic markers should not be taken as direct evidence for a population's future adaptive potential.

Identifying local adaptation has historically been attempted through common garden and reciprocal transplant experiments. However, such experiments are costly and, particularly for long-lived species like trees, time consuming or even unfeasible. Molecular genetic studies provide an alternative or complementary way to study adaptation. The development of next-generation sequencing technologies has opened up new avenues for exploring the basis of multi locus/gene variation and local adaptation outside of the common garden.

The use of genome scans, where a random sample of the genome is sequenced and then explored for genes under selection, is becoming an ever more utilised approach to study adaptation. Steane et al. (2014) performed a genome scan followed by outlier detection to study signatures of climate adaptation in red ironbark (Eucalyptus tricarpa) across an aridity gradient in south-eastern Australia. They identified 94 putatively adaptive loci, whose populationlevel frequencies correlated strongly with temperature and moisture availability, suggesting they have most likely 
been the targets of selection under differing environmental conditions. Similarly, by examining sequence and expression variation in candidate genes, Chen et al. (2012) showed that variation in bud set in Norway spruce (Picea abies) along a latitudinal gradient had in part resulted from local selection. These types of approaches can prove useful for assessing climate adaptation in species and help identify climate resilient populations (Steane et al. 2014), which are likely to be important to improve the adaptive capacity of a species and therefore should be a conservation priority (Breed et al. 2012c).

Recent advances in sequencing technologies have also allowed easier access to transcriptome data (Bouck and Vision 2007; Hudson 2008; Martin and Wang 2011). The transcriptome contains RNA sequences of all genes expressed within a given tissue, and can therefore be used to determine which genes are active as well as their level of activity for specific tissues or developmental stages. This information can provide insight into the genes responsible for local adaptation under distinct climatic conditions. Transcriptome sequencing of river red gum (Eucalyptus camaldulensis) seedlings from three populations enabled an exploration of differential gene expression under waterstressed conditions (Thumma et al. 2012). Differential expression of a host of genes was found between control and stressed conditions and nearly 3000 single nucleotide polymorphisms (SNPs) showed differential allelic expression, with a proportion of these shown to be under positive selection among the populations (Thumma et al. 2012). These types of analyses can help to reveal the underlying genetic mechanisms behind adaptation and plasticity, and enable us to identify genes that are important to plastic responses in a changing/stressful environment.

\section{Implications for conservation: what can we do?}

When incorporating climate vulnerability into conservation planning, species sensitivity, adaptive capacity, and exposure to change are all important (Dawson et al. 2011). In this review, we have focused on what constrains adaptive capacity, which will therefore affect the sensitivity of a species to change. In order to reduce the chances of population extirpation and species extinction, as well as help populations to continue to adapt under climate change, conservation strategies need to aim to increase adaptive capacity. The disparity between current species ranges and their ideal range under climate change, coupled with the fact that human activities have fragmented the landscape, has resulted in populations inhabiting areas that they are struggling to adapt to or migrate away from. This is where human-intervention via well-planned and managed conservation and restoration strategies is required.

\section{Biodiversity corridors}

The establishment of biodiversity corridors has been a promising solution for fragmentation issues (Hilty et al. 2006). For plants, it has been demonstrated that corridors can result in increased species richness in connected patches by promoting colonisation via increased seed deposition, increased pollen movement, and altered foraging by seed predators (Damschen et al. 2006). This increased species richness has also been shown to 'spill over' into areas surrounding the connected patches (Brudvig et al. 2009).

In terms of overcoming constraints to adaptation, corridors can enhance migration and gene flow (Fig. 1b, c) by connecting fragmented patches thus aiding seed and pollen dispersal and increasing effective population sizes (Tewksbury et al. 2002; Townsend and Levey 2005; Gilbert-Norton et al. 2010). In an experimental study into the effectiveness of corridors for connecting fragmented populations, it was shown that corridors increased movement of insects and birds between patches resulting in greater levels of pollen and seed dispersal respectively, thus increasing gene flow among fragmented populations (Tewksbury et al. 2002). The flow of adaptive alleles along corridors by connecting fragmented populations may assist in boosting population adaptive capacity as climate shifts (Fig. 1c). However, as yet, there is little to no empirical evidence as to whether corridors assist plant adaptation to climate change.

Corridors also act to restore disrupted habitats, increase niche availability, restore species' ranges, increase population sizes, and maintain plant-pollinator interactions (Hilty et al. 2006; Menz et al. 2011). However, the rate of climate change will have a significant impact on the success of corridors to assist plant migration (Renton et al. 2012, 2013). If rapid large-scale migrations are to be achieved principally via long-distance dispersal events then corridors may have limited impact in assisting such migrations (Pearson and Dawson 2005).

\section{Assisted migration}

For populations struggling to adapt and/or migrate (Fig. 1a-e), assisted migration is a strategy to help them reach more climatically suitable areas (Hoegh-Guldberg et al. 2008; Thomas 2011; Schwartz et al. 2012; Aitken and Whitlock 2013; Williams and Dumroese 2013). The term 'assisted migration' encompasses both movements within current species ranges-assisted gene flow-as well as assisted colonisation of areas outside of current rangestranslocations (Aitken and Whitlock 2013). For plants, assisted migration mainly involves selecting seeds of suitable provenance for use in revegetation and restoration. 
By carefully sourcing seed, genotypes can be migrated into populations via assisted gene flow (Broadhurst et al. 2008; Breed et al. 2012c). In the short term, this should increase mean survival rate and fecundity through genetic rescue, and in the long term the inflow of alleles from distant populations is likely to provide greater adaptive potential on which to build future evolutionary responses (Aitken and Whitlock 2013; Whiteley et al. 2015). For example, in the AdapTree project in British Columbia, Canada, the adaptive potential of tree populations is being used as a basis for selecting more climate resilient reforestation stocks (Wang et al. 2010; Alberto et al. 2013).

Assisted migration within current ranges (assisted gene flow) does not come without risks. It may lead to outbreeding depression if populations have been isolated for an extended period, and may also disrupt local adaptation to non-climatic factors (Weeks et al. 2011; Breed et al. 2012c). It would therefore be advisable that the level of local adaptation be assessed when implementing such practices (Aitken and Whitlock 2013) or, at the very least, risk assessments based on decision trees such as those outlined by Frankham et al. (2011) and Byrne et al. (2011) should be carried out.

An extension of assisted migration is to translocate species into novel habitats identified as suitable via modelling approaches (Hoegh-Guldberg et al. 2008; Schwartz et al. 2012; Williams and Dumroese 2013). This approach could prove particularly valuable in preserving narrowrange endemic species experiencing very rapid climate change and are unable to adapt or migrate quickly enough (Thomas 2011; Fig. 1a). Clearly, the movement of species outside their current range is not without risk, and may present an invasive problem (Thomas 2011; Schwartz et al. 2012), but translocations generally only occur for the most endangered species which are under threat in their current location and so any successfully established populations would be deemed a success.

\section{In situ conservation and protecting refugia}

In general, larger populations are at lower risk of extirpation, support higher levels of genetic diversity and promote the generation of novel genetic variation. Therefore, the maintenance of large populations should remain a key conservation priority. However, a critical issue is to identify which areas should receive the focus of conservation support and, in this context, identifying areas of historical and potential future refugia is important.

Refugia are areas that support a range of environmental conditions such that they offer relatively stable conditions within a landscape despite regional biotic and abiotic change. A range of cold-sensitive species retreated to refugia during cooler climatic conditions of the Quaternary period (generally areas of lower latitude and altitude that remained warmer) and then expanded again as the climate warmed (Lewis and Crawford 1995; Hewitt 2000, 2004). During the current period of warming we would expect heat-sensitive plants to move into refugia of higher latitude and altitude, where conditions remain cooler.

Areas with altitudinal diversity are likely to act as important refugia during the current period of warming, as species would only need to disperse over short distances to track preferred climatic conditions over an altitudinal rather than latitudinal gradient. Refugia also tend to maintain high genetic diversity and potentially harbour important adaptive variation; populations that have expanded from refugia in the past demonstrate lower genetic diversity than the refugial populations they expanded from (Lewis and Crawford 1995; Hewitt 2000, 2004). For in situ adaptation (Fig. 1d, e), conservation of refugia may be imperative for the maintenance of high adaptive capacity, with areas that have acted as multispecies refugia the greatest priority.

\section{Ex situ conservation and seed banks}

Climate change is likely to shift environments beyond the adaptive capacity of some species and communities, heightening extinction risk. An insurance policy against such losses of plant biodiversity is the use of seed banks (Hawkes et al. 2012; Raven et al. 2013). In this case, seed from populations or species demonstrated to be at extreme risk of extinction can be stored to ensure survival and the long-term maintenance of genetic diversity. Global projects, such as the Millennium Seed Bank Partnership coordinated by The Royal Botanic Gardens (Kew, UK) are working to collect and maintain storage of seeds from atrisk species. Through a concerted international effort the Millennium Seed Bank has bold aims of holding seed stores for $25 \%$ of the world's plant species by 2020 . Stored seed could later be used to reintroduce lost alleles to populations within the range as a type of assisted gene flow leading to genetic rescue (Aitken and Whitlock 2013; Whiteley et al. 2015). Seed bank resources could also form part of a 'Lazarus strategy' in the future, where species could be brought back from extinction in novel, climatically suitable areas. To these ends, careful consideration of sampling strategy is essential for effective seed banking, particularly if the overall aims are future reintroduction of populations with sufficient genetic diversity and adaptive potential (Hoban and Schlarbaum 2014; Guja et al. 2015). The costs of ex situ seed conservation also make it an extremely financially viable and attractive conservation strategy, with estimates of as little as $1 \%$ of in situ conservation efforts (Li and Pritchard 2009). However at some point restoration of communities will be required, which is 
notably more expensive than conservation activities to maintain a functioning system.

\section{Conclusions and future directions}

The survival of plant species through this next period of climate warming will depend on their ability to migrate, their genetic adaptive potential and their level of plasticity. Through past periods of climate change, migration to higher altitudes and latitudes to track preferred conditions might have been the default response. But under contemporary climate change, in a fragmented landscape, migration is likely to be impeded by a whole host of extra factors such as the fast rate of climate change, changed land use, habitat and population fragmentation, and absent niches. These factors can each constrain migration, keeping species trapped within their current range, or even restricting their range further as conditions at lower latitudes and altitudes exceed thermal limits.

If migration is hampered then adapting to novel conditions may be the answer to species persistence. By assessing the current plastic responses and genetic variability through the use of phenotypic clines along climatic gradients, common garden experiments, and genomic methods, researchers can discover the adaptive potential of plant populations to better inform conservation strategies. The species under most threat will be those in small populations with low genetic diversity, inhabiting the edge of suitable habitat (e.g. top of a mountain or along the coast). In the absence of successful in situ adaptation, these species will become under increasing threat of extinction.

In order to improve our understanding of adaptation under climate change, further exploration of the evolution of simple and more complex adaptive traits under different climate scenarios is needed. This could be achieved by simulating the effects of, for example, population size, levels of gene flow and genetic architectures to explore how changes in selection impacts the likelihood of successful adaptation to projected future environments. Mathematical and simulation tools have been developed to this end. For example, the software ALADYN (http://www. katja-schiffers.eu/research.html) has been used to investigate the spread of adaptive climate-related alleles in a hypothetical species (Schiffers et al. 2013). It was demonstrated that under gradual warming, adaptive alleles easily spread throughout a species range in the absence of local adaptation, but the presence of local adaptation hampered the spread of climate-related adaptive alleles due to increased mortality of new migrants. Similarly, the relative roles of mortality, dispersal ability and age of maturation in determining speed of adaptation have been investigated using a modeling approach for Scots pine
(Pinus sylvestris) and Silver birch (Betula pendula) $(\mathrm{Ku}-$ parinen et al. 2010). Information from these types of simulation studies, which account for evolutionary processes, will improve predictions of the likely outcomes for plant populations under climate change and can therefore be harnessed for evidence-based management actions.

Conservation and restoration efforts, through a combination of revegetation using pre-adapted and diverse provenances and the establishment of biodiversity corridors, as well as the use of seed banks, should be focused on the species identified as most threatened by climate change. The effectiveness of these strategies is yet to be fully assessed and there is a sense of great urgency for future research into conservation and restoration management actions to overcome adaptive constraints. For example, long-term field trials to explore the effectiveness of predictive or refugial provenancing for building climate-resilient plant populations would provide invaluable data to this end.

Acknowledgments The authors wish to thank the Australian Research Council for funding support (LP110100721 awarded to AJL; DE150100542 awarded to MFB; DP150103414 awarded to AJL and MFB), the South Australian Premier's Science and Research Fund awarded to AJL, and the Field Naturalist Society of South Australia Lirabenda Endowment Fund awarded to MJC. The funding bodies played no role in the writing of this review or in the decision to submit it for publication.

Open Access This article is distributed under the terms of the Creative Commons Attribution 4.0 International License (http://crea tivecommons.org/licenses/by/4.0/), which permits unrestricted use, distribution, and reproduction in any medium, provided you give appropriate credit to the original author(s) and the source, provide a link to the Creative Commons license, and indicate if changes were made.

\section{References}

Afkhami ME, McIntyre PJ, Strauss SY (2014) Mutualist-mediated effects on species' range limits across large geographic scales. Ecol Lett 17:1265-1273

Aguilar R, Quesada M, Ashworth L, Herrerias-Diego Y, Lobo J (2008) Genetic consequences of habitat fragmentation in plant populations: susceptible signals in plant traits and methodological approaches. Mol Ecol 17:5177-5188

Aitken SN, Whitlock MC (2013) Assisted gene flow to facilitate local adaptation to climate change. Annu Rev Ecol Evol Syst 44:367-388

Aitken SN, Yeaman S, Holliday JA, Wang T, Curtis-McLane S (2008) Adaptation, migration or extirpation: climate change outcomes for tree populations. Evol Appl 1:95-111

Alberto FJ, Aitken SN, Alía R, González-Martínez SC, Hänninen H, Kremer A, Lefèvre F, Lenormand T, Yeaman S, Whetten R, Savolainen O (2013) Potential for evolutionary responses to climate change - evidence from tree populations. Glob Change Biol 19:1645-1661

Alsos IG, Ehrich D, Thuiller W, Eidesen PB, Tribsch A, Schönswetter P, Lagaye C, Taberlet P, Brochmann C (2012) Genetic 
consequences of climate change for northern plants. Proc R Soc B Biol Sci 279:2042-2051

Anderson JT, Willis JH, Mitchell-Olds T (2011) Evolutionary genetics of plant adaptation. Trends Genet 27:258-266

Anderson JT, Panetta AM, Mitchell-Olds T (2012) Evolutionary and ecological responses to anthropogenic climate change: update on anthropogenic climate change. Plant Physiol 160: $1728-1740$

Bacles CFE, Lowe AJ, Ennos RA (2006) Effective seed dispersal across a fragmented landscape. Science 311:628

Barrett RD, Schluter D (2008) Adaptation from standing genetic variation. Trends Ecol Evol 23:38-44

Beckage B, Osborne B, Gavin DG, Pucko C, Siccama T, Perkins T (2008) A rapid upward shift of a forest ecotone during 40 years of warming in the Green Mountains of Vermont. Proc Natl Acad Sci USA 105:4197-4202

Bennington CC, Fetcher N, Vavrek MC, Shaver GR, Cummings KJ, McGraw JB (2012) Home site advantage in two long-lived arctic plant species: results from two 30-year reciprocal transplant studies. J Ecol 100:841-851

Boeye J, Travis JMJ, Stoks R, Bonte D (2012) More rapid climate change promotes evolutionary rescue through selection for increased dispersal distance. Evol Appl 6:353-364

Bossdorf O, Richards CL, Pigliucci M (2008) Epigenetics for ecologists. Ecol Lett 11:106-115

Bouck A, Vision T (2007) The molecular ecologist's guide to expressed sequence tags. Mol Ecol 16:907-924

Bragg JG, Supple MA, Andrew RL, Borevitz JO (2015) Genomic variation across landscapes: insights and applications. New Phytol 207:953-967

Breed MF, Ottewell KM, Gardner MG, Lowe AJ (2011) Clarifying climate change adaptation responses for scattered trees in modified landscapes. J Appl Ecol 48:637-641

Breed MF, Gardner MG, Ottewell KM, Navarro CM, Lowe AJ (2012a) Shifts in reproductive assurance strategies and inbreeding costs associated with habitat fragmentation in Central American mahogany. Ecol Lett 15:444-452

Breed MF, Ottewell KM, Gardner MG, Marklund MH, Stead MG, Harris JB, Lowe AJ (2012b) Mating system and early viability resistance to habitat fragmentation in a bird-pollinated eucalypt. Heredity. doi:10.1038/hdy.2012.72

Breed MF, Stead MG, Ottewell KM, Gardner MG, Lowe AJ (2012c) Which provenance and where? Seed sourcing strategies for revegetation in a changing environment. Conserv Genet 14:1-10

Breed MF, Christmas MJ, Lowe AJ (2014) Higher levels of multiple paternities increase seedling survival in the long-lived tree Eucalyptus gracilis. PLoS One 9:e90478

Breed MF, Ottewell KM, Gardner MG, Marklund MHK, Dormontt EE, Lowe A (2015) Mating patterns and pollinator mobility are critical traits in forest fragmentation genetics. Heredity 115:100-107

Bresson CC, Vitasse Y, Kremer A, Delzon S (2011) To what extent is altitudinal variation of functional traits driven by genetic adaptation in European oak and beech? Tree Physiol 31:1164-1174

Broadhurst LM, Lowe A, Coates DJ, Cunningham SA, McDonald M, Vesk PA, Yates C (2008) Seed supply for broadscale restoration: maximizing evolutionary potential. Evol Appl 1:587-597

Brook BW, Sodhi NS, Bradshaw CJ (2008) Synergies among extinction drivers under global change. Trends Ecol Evol 23: 453-460

Brooker RW, Maestre FT, Callaway RM, Lortie CL, Cavieres LA, Kunstler G, Liancourt P, Tielbörger K, Travis JM, Anthelme F (2008) Facilitation in plant communities: the past, the present, and the future. J Ecol 96:18-34

Brown J, Millner F (1989) Aspects of the meteorology and hydrology of the Australian Alps. Australian Alps National Parks Liaison Committee, Canberra, pp 297-329
Brudvig LA, Damschen EI, Tewksbury JJ, Haddad NM, Levey DJ (2009) Landscape connectivity promotes plant biodiversity spillover into non-target habitats. Proc Natl Acad Sci 106:9328-9332

Byrne M, Stone L, Millar MA (2011) Assessing genetic risk in revegetation. J Appl Ecol 48:1365-1373

Cahill AE, Aiello-Lammens ME, Fisher-Reid MC, Hua X, Karanewsky CJ, Ryu HY, Sbeglia GC, Spagnolo F, Waldron JB, Warsi O (2013) How does climate change cause extinction? Proc R Soc B Biol Sci 280. doi:10.1098/rspb.2012.1890

Chen J, Källman T, Ma X, Gyllenstrand N, Zaina G, Morgante M, Bousquet J, Eckert A, Wegrzyn J, Neale D (2012) Disentangling the roles of history and local selection in shaping clinal variation of allele frequencies and gene expression in Norway spruce (Picea abies). Genetics 191:865-881

Corlett RT, Westcott DA (2013) Will plant movements keep up with climate change? Trends Ecol Evol 28:482-488

Damschen EI, Haddad NM, Orrock JL, Tewksbury JJ, Levey DJ (2006) Corridors increase plant species richness at large scales. Science 313:1284-1286

Davies S, White A, Lowe A (2004) An investigation into effects of long-distance seed dispersal on organelle population genetic structure and colonization rate: a model analysis. Heredity 93:566-576

Davis MB (1981) Quaternary history and the stability of forest communities. Forest Succession. Springer, New York, pp 132-153

Davis MB, Shaw RG (2001) Range shifts and adaptive responses to quaternary climate change. Science 292:673-679

Dawson TP, Jackson ST, House JI, Prentice IC, Mace GM (2011) Beyond predictions: biodiversity conservation in a changing climate. Science 332:53-58

Eckert CG, Kalisz S, Geber MA, Sargent R, Elle E, Cheptou P-O, Goodwillie C, Johnston MO, Kelly JK, Moeller DA (2010) Plant mating systems in a changing world. Trends Ecol Evol 25:35-43

Etterson JR (2000) Evolutionary Potential of the Annual Legume, Chamaecrista Fasciculata, in Relation to Global Warming. Doctoral Thesis, University of Minnesota

Etterson JR (2004) Evolutionary potential of Chamaecrista fasciculata in relation to climate change. I. Clinal patterns of selection along an environmental gradient in the Great Plains. Evolution 58:1446-1456

Etterson JR, Shaw RG (2001) Constraint to adaptive evolution in response to global warming. Science 294:151-154

Feeley KJ, Silman MR (2010) Land-use and climate change effects on population size and extinction risk of Andean plants. Glob Change Biol 16:3215-3222

Fieldes MA, Amyot LM (1999) Epigenetic control of early flowering in flax lines induced by 5-azacytidine applied to germinating seed. J Hered 90:199-206

Frankham R, Ballou JD, Eldridge MD, Lacy RC, Ralls K, Dudash MR, Fenster CB (2011) Predicting the probability of outbreeding depression. Conserv Biol 25:465-475

Franks SJ, Hoffmann AA (2012) Genetics of climate change adaptation. Annu Rev Genet 46:185-208

Franks SJ, Sim S, Weis AE (2007) Rapid evolution of flowering time by an annual plant in response to a climate fluctuation. Proc Natl Acad Sci 104:1278-1282

Franks SJ, Weber JJ, Aitken SN (2014) Evolutionary and plastic responses to climate change in terrestrial plant populations. Evol Appl 7:123-139

Frei ER, Ghazoul J, Matter P, Heggli M, Pluess AR (2014) Plant population differentiation and climate change: responses of grassland species along an elevational gradient. Glob Change Biol 20:441-455

Ghalambor CK, McKay JK, Carroll SP, Reznick DN (2007) Adaptive versus non-adaptive phenotypic plasticity and the potential for 
contemporary adaptation in new environments. Funct Ecol 21:394-407

Gilbert-Norton L, Wilson R, Stevens JR, Beard KH (2010) A metaanalytic review of corridor effectiveness. Conserv Biol 24:660-668

Guja LK, Broadhurst LM, Brown AH, Bush D, Cochrane A, Merritt DJ, Offord CA, Rossetto M, Wallace MJ, Wood J (2015) Genetic diversity is a significant but not the only consideration for effective ex situ plant conservation: response to Hoban and Schlarbaum. Biol Conserv 184:467-468

Hamann A, Roberts DR, Barber QE, Carroll C, Nielsen SE (2015) Velocity of climate change algorithms for guiding conservation and management. Glob Change Biol 21:997-1004

Hawkes JG, Maxted N, Ford-Lloyd BV (2012) The ex situ conservation of plant genetic resources. Springer Science and Business Media, Netherlands

Hennessy K, Whetton P, Smith I, Bathols J, Hutchinson M, Sharples J (2003) The impact of climate change on snow conditions in mainland Australia. CSIRO Atmospheric Research, Aspendale

Hermisson J, Pennings PS (2005) Soft sweeps molecular population genetics of adaptation from standing genetic variation. Genetics 169:2335-2352

Hewitt G (2000) The genetic legacy of the Quaternary ice ages. Nature 405:907-913

Hewitt G (2004) Genetic consequences of climatic oscillations in the Quaternary. Philos Trans R Soc Lond B Biol Sci 359:183-195

Hickling R, Roy DB, Hill JK, Fox R, Thomas CD (2006) The distributions of a wide range of taxonomic groups are expanding polewards. Glob Change Biol 12:450-455

Higgins SI, Lavorel S, Revilla E (2003) Estimating plant migration rates under habitat loss and fragmentation. Oikos 101:354-366

Hilty JA, Lidicker WZ, Merenlender AM (2006) Corridor ecology: the science and practice of linking landscapes for biodiversity conservation. Island Press, Washington, DC

Hoban S, Schlarbaum S (2014) Optimal sampling of seeds from plant populations for ex situ conservation of genetic biodiversity, considering realistic population structure. Biol Conserv 177:90-99

Hoegh-Guldberg O, Hughes L, McIntyre S, Lindenmayer D, Parmesan C, Possingham H, Thomas C (2008) Assisted colonization and rapid climate change. Science 321:345-346

Hoffmann AA, Sgro CM (2011) Climate change and evolutionary adaptation. Nature 470:479-485

Hoffmann A, Griffin P, Dillon S, Catullo R, Rane R, Byrne M, Jordan R, Oakeshott J, Weeks A, Joseph L (2015) A framework for incorporating evolutionary genomics into biodiversity conservation and management. Clim Change Responses 2:1-24

Honnay O, Jacquemyn H (2007) Susceptibility of common and rare plant species to the genetic consequences of habitat fragmentation. Conserv Biol 21:823-831

Hudson ME (2008) Sequencing breakthroughs for genomic ecology and evolutionary biology. Mol Ecol Resour 8:3-17

Ibanez I, Clark JS, Dietze MC (2008) Evaluating the sources of potential migrant species: implications under climate change. Ecol Appl 18:1664-1678

Ibanez I, Clark JS, Dietze MC (2009) Estimating colonization potential of migrant tree species. Glob Change Biol 15:1173-1188

Iverson LR, Schwartz M, Prasad AM (2004a) How fast and far might tree species migrate in the eastern United States due to climate change? Glob Ecol Biogeogr 13:209-219

Iverson LR, Schwartz M, Prasad AM (2004b) Potential colonization of newly available tree-species habitat under climate change: an analysis for five eastern US species. Landsc Ecol 19:787-799

Jump AS, Peñuelas J (2005) Running to stand still: adaptation and the response of plants to rapid climate change. Ecol Lett 8: $1010-1020$
Kelly CK, Chase MW, De Bruijn A, Fay MF, Woodward FI (2003) Temperature-based population segregation in birch. Ecol Lett 6:87-89

King G, Herstrom A (1997) Holocene migration rates objectively determined from fossil pollen data. Springer-Verlag, New York

Kremer A, Ronce O, Robledo-Arnuncio JJ, Guillaume F, Bohrer G, Nathan R, Bridle JR, Gomulkiewicz R, Klein EK, Ritland K (2012) Long-distance gene flow and adaptation of forest trees to rapid climate change. Ecol Lett 15:378-392

Kremer A, Potts BM, Delzon S (2014) Genetic divergence in forest trees: understanding the consequences of climate change. Funct Ecol 28:22-36

Krushelnycky PD, Loope LL, Giambelluca TW, Starr F, Starr K, Drake DR, Taylor AD, Robichaux RH (2013) Climate-associated population declines reverse recovery and threaten future of an iconic high-elevation plant. Glob Change Biol 19:911-922

Kuparinen A, Savolainen O, Schurr FM (2010) Increased mortality can promote evolutionary adaptation of forest trees to climate change. Forest Ecol Manag 259:1003-1008

Lau JA, Lennon JT (2012) Rapid responses of soil microorganisms improve plant fitness in novel environments. Proc Natl Acad Sci 109:14058-14062

Leimu R, Fischer M (2008) A meta-analysis of local adaptation in plants. PLoS One 3:e4010

Lewis PO, Crawford DJ (1995) Pleistocene refugium endemics exhibit greater allozymic diversity than widespread congeners in the genus Polygonella (Polygonaceae). Am J Bot 82:141-149

Li D-Z, Pritchard HW (2009) The science and economics of ex situ plant conservation. Trends Plant Sci 14:614-621

Loarie SR, Duffy PB, Hamilton H, Asner GP, Field CB, Ackerly DD (2009) The velocity of climate change. Nature 462:1052-1055

Lovell JT, Juenger TE, Michaels SD, Lasky JR, Platt A, Richards JH, Yu X, Easlon HM, Sen S, McKay JK (2013) Pleiotropy of FRIGIDA enhances the potential for multivariate adaptation. Proc R Soc Lond B Biol Sci 280:20131043

Lowe A, Boshier D, Ward M, Bacles C, Navarro C (2005a) Genetic resource loss following habitat fragmentation and degradation; reconciling predicted theory with empirical evidence. Heredity 95:255-273

Lowe A, Unsworth C, Gerber S, Davies S, Munro R, Kelleher C, King A, Brewer S, White A, Cottrell J (2005b) Route, speed and mode of oak postglacial colonisation across the British Isles: integrating molecular ecology, palaeoecology and modelling approaches. Trans Proc Bot Soc Edinb Bot Soc Edinb Trans 57:59-81

Lowe AJ, Cavers S, Boshier D, Breed MF, Hollingsworth P (2015) The resilience of forest fragmentation genetics-no longer a paradox-we were just looking in the wrong place. Heredity 115:97-99

MacDonald GM (1993) Fossil pollen analysis and the reconstruction of plant invasions. Academic Press, San Diego

Maron JL, Vilà M, Bommarco R, Elmendorf S, Beardsley P (2004) Rapid evolution of an invasive plant. Ecol Monogr 74:261-280

Martin JA, Wang Z (2011) Next-generation transcriptome assembly. Nat Rev Genet 12:671-682

Mayhew PJ, Jenkins GB, Benton TG (2008) A long-term association between global temperature and biodiversity, origination and extinction in the fossil record. Proc R Soc B 275:47-53

McLachlan JS, Clark JS, Manos PS (2005) Molecular indicators of tree migration capacity under rapid climate change. Ecology 86:2088-2098

McLaughlin JF, Hellmann JJ, Boggs CL, Ehrlich PR (2002) Climate change hastens population extinctions. Proc Natl Acad Sci 99:6070-6074

Menz MH, Phillips RD, Winfree R, Kremen C, Aizen MA, Johnson SD, Dixon KW (2011) Reconnecting plants and pollinators: 
challenges in the restoration of pollination mutualisms. Trends Plant Sci 16:4-12

Mittell EA, Nakagawa S, Hadfield JD (2015) Are molecular markers useful predictors of adaptive potential. Ecol Lett 18:772-778

Molinier J, Ries G, Zipfel C, Hohn B (2006) Transgeneration memory of stress in plants. Nature 442:1046-1049

Montesinos-Navarro A, Wig J, Pico FX, Tonsor SJ (2011) Arabidopsis thaliana populations show clinal variation in a climatic gradient associated with altitude. New Phytol 189:282-294

Nei M, Maruyama T, Chakraborty R (1975) The bottleneck effect and genetic variability in populations. Evolution 29:1-10

Nicotra AB, Atkin OK, Bonser SP, Davidson AM, Finnegan EJ, Mathesius U, Poot P, Purugganan MD, Richards CL, Valladares F, van Kleunen M (2010) Plant phenotypic plasticity in a changing climate. Trends Plant Sci 15:684-692

Norberg J, Urban MC, Vellend M, Klausmeier CA, Loeuille N (2012) Eco-evolutionary responses of biodiversity to climate change. Nat Clim Change 2:747-751

Pardi MI, Smith FA (2012) Paleoecology in an era of climate change: how the past can provide insights into the future. Paleontology in Ecology and Conservation. Springer, Berlin, p 93-116

Parmesan C (2006) Ecological and evolutionary responses to recent climate change. Annu Rev Ecol Evol Syst 37:637-669

Parmesan C, Yohe G (2003) A globally coherent fingerprint of climate change impacts across natural systems. Nature 421: $37-42$

Pearson RG, Dawson TP (2005) Long-distance plant dispersal and habitat fragmentation: identifying conservation targets for spatial landscape planning under climate change. Biol Conserv 123: 389-401

Pellissier L, Pinto-Figueroa E, Niculita-Hirzel H, Moora M, Villard L, Goudet J, Guex N, Pagni M, Xenarios I, Sanders I (2013) Plant species distributions along environmental gradients: do belowground interactions with fungi matter? Front Plant Sci 4:500

Petit RJ, Hampe A (2006) Some evolutionary consequences of being a tree. Ann Rev Ecol Evol Syst 37:187-214

Petit RJ, Brewer S, Bordács S, Burg K, Cheddadi R, Coart E, Cottrell J, Csaikl UM, van Dam B, Deans JD (2002) Identification of refugia and post-glacial colonisation routes of European white oaks based on chloroplast DNA and fossil pollen evidence. For Ecol Manag 156:49-74

Phillips BL, Brown GP, Shine R (2010) Life-history evolution in range-shifting populations. Ecology 91:1617-1627

Pickering C, Hill W, Green K (2008) Vascular plant diversity and climate change in the alpine zone of the Snowy Mountains, Australia. Biodivers Conserv 17:1627-1644

Pounds JA, Bustamante MR, Coloma LA, Consuegra JA, Fogden MP, Foster PN, La Marca E, Masters KL, Merino-Viteri A, Puschendorf R, Ron SR, Sanchez-Azofeifa GA, Still CJ, Young BE (2006) Widespread amphibian extinctions from epidemic disease driven by global warming. Nature 439:161-167

Raven PH, Guerrant EO, Havens K, Maunder M (2013) Ex situ plant conservation: supporting species survival in the wild. Island Press, Washington

Reed TE, Schindler DE, Waples RS (2011) Interacting effects of phenotypic plasticity and evolution on population persistence in a changing climate. Conserv Biol 25:56-63

Rejmánek M, Richardson DM (1996) What attributes make some plant species more invasive? Ecology 77:1655-1661

Renton M, Shackelford N, Standish RJ (2012) Habitat restoration will help some functional plant types persist under climate change in fragmented landscapes. Glob Change Biol 18:2057-2070

Renton M, Childs S, Standish R, Shackelford N (2013) Plant migration and persistence under climate change in fragmented landscapes: does it depend on the key point of vulnerability within the lifecycle? Ecol Model 249:50-58
Richter S, Kipfer T, Wohlgemuth T, Guerrero CC, Ghazoul J, Moser B (2012) Phenotypic plasticity facilitates resistance to climate change in a highly variable environment. Oecologia 169:269-279

Rico L, Ogaya R, Barbeta A, Penuelas J (2014) Changes in DNA methylation fingerprint of Quercus ilex trees in response to experimental field drought simulating projected climate change. Plant Biol 16:419-427

Rival A, Jaligot E, Beulé T (2012) Plant epigenetics: beyond the double helix. Acta Hortic 929:315-325

Savolainen O, Lascoux M, Merila J (2013) Ecological genomics of local adaptation. Nat Rev Genet 14:807-820

Schiffers K, Bourne EC, Lavergne S, Thuiller W, Travis JMJ (2013) Limited evolutionary rescue of locally adapted populations facing climate change. Philos Trans R Soc Lond B Biol Sci 368:20120083

Schoville SD, Bonin A, François O, Lobreaux S, Melodelima C, Manel S (2012) Adaptive genetic variation on the landscape: methods and cases. Annu Rev Ecol Evol Syst 43:23-43

Schwartz MW, Hellmann JJ, McLachlan JM, Sax DF, Borevitz JO, Brennan J, Camacho AE, Ceballos G, Clark JR, Doremus H (2012) Managed relocation: integrating the scientific, regulatory, and ethical challenges. Bioscience 62:732-743

Sexton JP, Strauss SY, Rice KJ (2011) Gene flow increases fitness at the warm edge of a species' range. Proc Natl Acad Sci 108: 11704-11709

Sexton JP, Hangartner SB, Hoffmann AA (2014) Genetic isolation by environment or distance: which pattern of gene flow is most common? Evolution 68:1-15

Shafer AB, Wolf JB, Alves PC, Bergström L, Bruford MW, Brännström I, Colling G, Dalén L, De Meester L, Ekblom R (2015) Genomics and the challenging translation into conservation practice. Trends Ecol Evol 30:78-87

Sork VL, Smouse PE (2006) Genetic analysis of landscape connectivity in tree populations. Landsc Ecol 21:821-836

Steane DA, Potts BM, McLean E, Prober SM, Stock WD, Vaillancourt RE, Byrne M (2014) Genome-wide scans detect adaptation to aridity in a widespread forest tree species. Mol Ecol 23:2500-2513

Sturm M, Racine C, Tape K (2001) Increasing shrub abundance in the Arctic. Nature 411:546-547

Tewksbury JJ, Levey DJ, Haddad NM, Sargent S, Orrock JL, Weldon A, Danielson BJ, Brinkerhoff J, Damschen EI, Townsend P (2002) Corridors affect plants, animals, and their interactions in fragmented landscapes. Proc Natl Acad Sci 99:12923-12926

Thomas CD (2011) Translocation of species, climate change, and the end of trying to recreate past ecological communities. Trends Ecol Evol 26:216-221

Thomas CD, Cameron A, Green RE, Bakkenes M, Beaumont LJ, Collingham YC, Erasmus BFN, De Siqueira MF, Grainger A, Hannah L (2004) Extinction risk from climate change. Nature 427:145-148

Thumma BR, Sharma N, Southerton SG (2012) Transcriptome sequencing of Eucalyptus camaldulensis seedlings subjected to water stress reveals functional single nucleotide polymorphisms and genes under selection. BMC Genom 13:364

Tiffin P, Ross-Ibarra J (2014) Advances and limits of using population genetics to understand local adaptation. Trends Ecol Evol 29:673-680

Townsend PA, Levey DJ (2005) An experimental test of whether habitat corridors affect pollen transfer. Ecology 86:466-475

Urban MC, Tewksbury JJ, Sheldon KS (2012) On a collision course: competition and dispersal differences create no-analogue communities and cause extinctions during climate change. Proc R Soc B Biol Sci 279:2072-2080

Uribe-Salas D, Sáenz-Romero C, González-Rodríguez A, TéllezValdéz O, Oyama K (2008) Foliar morphological variation in the 
white oak Quercus rugosa Née (Fagaceae) along a latitudinal gradient in Mexico: potential implications for management and conservation. For Ecol Manag 256:2121-2126

Vitti JJ, Grossman SR, Sabeti PC (2013) Detecting natural selection in genomic data. Annu Rev Genet 47:97-120

Vranckx G, Jacquemyn H, Muys B, Honnay O (2012) Meta-analysis of susceptibility of woody plants to loss of genetic diversity through habitat fragmentation. Conserv Biol 26:228-237

Walther GR (2003) Plants in a warmer world. Perspect Plant Ecol Evol Syst 6:169-185

Wang T, O'Neill GA, Aitken SN (2010) Integrating environmental and genetic effects to predict responses of tree populations to climate. Ecol Appl 20:153-163

Wang R, Compton SG, Chen XY (2011) Fragmentation can increase spatial genetic structure without decreasing pollen-mediated gene flow in a wind-pollinated tree. Mol Ecol 20:4421-4432

Weeks AR, Sgro CM, Young AG, Frankham R, Mitchell NJ, Miller KA, Byrne M, Coates DJ, Eldridge MD, Sunnucks P, Breed MF, James EA, Hoffmann AA (2011) Assessing the benefits and risks of translocations in changing environments: a genetic perspective. Evol Appl 4:709-725

Whiteley AR, Fitzpatrick SW, Funk WC, Tallmon DA (2015) Genetic rescue to the rescue. Trends Ecol Evol 30:42-49

Willi Y, Van Buskirk J, Hoffmann AA (2006) Limits to the adaptive potential of small populations. Ann Rev Ecol Evol Syst 37:433-458

Williams MI, Dumroese RK (2013) Preparing for climate change: forestry and assisted migration. J For 111:287-297

Woods E, Hastings AP, Turley NE, Heard SB, Agrawal AA (2012) Adaptive geographical clines in the growth and defense of a native plant. Ecol Monogr 82:149-168

Wright S (1943) Isolation by distance. Genetics 28:114

Yakovlev IA, Asante DK, Fossdal CG, Junttila O, Johnsen O (2011) Differential gene expression related to an epigenetic memory affecting climatic adaptation in Norway spruce. Plant Sci 180:132-139

Zhu K, Woodall CW, Clark JS (2012) Failure to migrate: lack of tree range expansion in response to climate change. Glob Change Biol 18:1042-1052 